\title{
Physical Properties of Two Core Samples from Well 34-9RD2 at the Coso Geothermal Field, California
}

By C.A. Morrow ${ }^{1}$ and D.A. Lockner ${ }^{1}$

Open-File Report 2006-1230

2006

Any use of trade, firm, or product names is for descriptive purposes only and does not imply endorsement by the U.S. Government.

U.S. DEPARTMENT OF THE INTERIOR

U.S. GEOLOGICAL SURVEY

${ }^{1}$ Menlo Park, Calif. 


\section{U.S. Department of the Interior DIRK KEMPTHORNE, Secretary}

\section{U.S. Geological Survey \\ P. Patrick Leahy, Acting Director}

U.S. Geological Survey, Reston, Virginia 2006

For product and ordering information:

World Wide Web: http://www.usgs.gov/pubprod/

Telephone: 1-888-ASK-USGS

For more information on the USGS - the Federal source for science about the Earth, its natural and living resources, natural hazards, and the environment:

World Wide Web: http://www.usgs.gov/

Telephone: 1-888-ASK-USGS

Any use of trade, product, or firm names is for descriptive purposes only and does not imply endorsement by the U.S. Government.

Although this report is in the public domain, permission must be secured from the individual copyright owners to reproduce any copyrighted material contained within this report. 


\section{Introduction}

The Coso geothermal field, located along the Eastern California Shear Zone, is composed of fractured granitic rocks above a shallow heat source. Temperatures exceed $640^{\circ} \mathrm{F}\left(\sim 338^{\circ} \mathrm{C}\right)$ at a depth of less than 10000 feet $(3 \mathrm{~km})$. Permeability varies throughout the geothermal field due to the competing processes of alteration and mineral precipitation, acting to reduce the interconnectivity of faults and fractures, and the generation of new fractures through faulting and brecciation. Currently, several hot regions display very low permeability, not conducive to the efficient extraction of heat. Because high rates of seismicity in the field indicate that the area is highly stressed, enhanced permeability can be stimulated by increasing the fluid pressure at depth to induce faulting along the existing network of fractures. Such an Enhanced Geothermal System (EGS), planned for well 46A-19RD, would greatly facilitate the extraction of geothermal fluids from depth by increasing the extent and depth of the fracture network.

In order to prepare for and interpret data from such a stimulation experiment, the physical properties and failure behavior of the target rocks must be fully understood. Various diorites and granodiorites are the predominant rock types in the target area of the well, which will be pressurized from 10000 feet measured depth (MD) (3048m MD) to the bottom of the well at 13000 feet MD (3962m MD). Because there are no core rocks currently available from well 46A-19RD, we report here on the results of compressive strength, frictional sliding behavior, and elastic measurements of a granodiorite and diorite from another well, 34-9RD2, at the Coso site. Rocks cored from well 34-9RD2 are the deepest samples to date available for testing, and are representative of rocks from the field in general.

\section{Sample Description}

Core samples of a granodiorite and an altered and healed diorite were obtained from well 34-9RD2 at the Coso geothermal field. The granodiorite, from a depth interval of 8406 to 8407 feet (B3 R3, 1b and 1c, i.e., Box and Run numbers plus sample ID) was light-colored and weakly foliated. The diorite, from a depth interval of 7973' 11 " to 7974' 7" (B1 R1, 1f and 1g) was dark colored, with many healed fractures and strong foliation. These samples are similar to the rocks at the target stimulation depth in the ESG well 46A-19RD. Detailed mineralogy is pending thin section and XRD analysis.

\section{Procedure}

\section{Porosity and Density}

Porosity and density measurements were made on two samples each of the granodiorite B3 R3 and the altered and healed diorite B1 R1. Cylindrical samples, 2.54 $\mathrm{cm}$ in diameter and $2.54 \mathrm{~cm}$ long, were dried overnight at $100^{\circ} \mathrm{C}$ to remove residual water. They were then weighed to determine the dry weight, $W_{d}$, and dry density, $\rho_{\text {dry }}$. The samples were evacuated for 2 hours, and submerged in distilled water under vacuum for an additional 8 hours to ensure full saturation. They were then reweighed while 
suspended in water to determine the wet submerged weight, $\mathrm{W}_{\mathrm{w}}$. Connected porosity, $\Phi$, is calculated from

$$
\Phi=1-\left[\left(\mathrm{W}_{\mathrm{d}}-\mathrm{W}_{\mathrm{w}}\right) / \mathrm{V}\right]
$$

where $\mathrm{V}$ is the sample volume. Wet density, $\rho_{\text {wet }}$, was calculated by adding the density of the water-filled voids (porosity times the density of water, $\rho_{\text {water }}$ ) to the dry density:

$$
\rho_{\text {sat }}=\rho_{\text {dry }}+\Phi \rho_{\text {water }}
$$

\section{Strength}

Room temperature triaxial strength tests were performed in the laboratory on cylindrical samples $2.54 \mathrm{~cm}$ in diameter and $5.59 \mathrm{~cm}$ long. Samples were tested under room-dry (as received) conditions. They were jacketed in polyurethane sleeves and secured between steel endplugs with hose clamps. Confining pressures were chosen relative to the estimated in situ pressure at a target stimulation depth of $10,000 \mathrm{ft}(3048 \mathrm{~m})$ based on an average rock density deduced from in situ density logs.

$\begin{array}{lll}\text { Confining Pressure } & \% \text { of Confining Pressure at Target Depth } \\ \text { unconfined } & 0 & \\ 13.0 \mathrm{MPa} & 25 & \\ 26.0 \mathrm{MPa} & 50 & \\ 52.1 \mathrm{MPa} & 100 \quad \text { Target Depth } \\ 78.2 \mathrm{MPa} & 150 & \end{array}$

For the first three pressure conditions listed above, an axial load was applied to the samples at a rate of $1 \mathrm{~mm} / \mathrm{sec}$ for $5 \mathrm{~mm}$ of axial displacement (shortening), during which time the samples failed and then slid on the newly formed shear fractures. For samples at the two highest confining pressures of 52.1 and $78.2 \mathrm{MPa}$, axial and transverse strain gauges were affixed to the sides of the cores to observe strain behavior during testing. For these samples, deformation proceeded in two phases. First, confining pressure was increased slowly to the desired level, then reduced by $10 \mathrm{MPa}$, and increased back up by $10 \mathrm{MPa}$ to the initial pressure. In this way, the bulk modulus could be determined (during the pressure cycling portion of the loading) without the effects of sample hysteresis from the initial loading. Next, the samples were sheared at an axial shortening rate of $1 \mathrm{~mm} / \mathrm{sec}$ until the axial load reached a value of roughly half of the estimated failure strength. The load was then decreased by $100 \mathrm{MPa}$, and increased by $100 \mathrm{MPa}$ back to the initial value. The samples were then removed from the vessel. The stress cycling under axial load enabled us to calculate Poisson's ratio, Young's modulus and the stiffness of the samples, as before, without the effects of sample hysteresis. In the second phase of these higher pressure experiments, the samples were disconnected from the strain-measuring apparatus, re-pressurized to the appropriate confining pressures and sheared at $1 \mathrm{~mm} / \mathrm{sec}$ for $5 \mathrm{~mm}$ of axial shortening, in the same fashion as the first three lower-pressure experiments. Pressures and displacements were maintained by a computer-controlled servomechanism and recorded by a data acquisition system once per second. Accuracy for the confining pressure was $\pm 0.05 \mathrm{MPa}$; for $\sigma_{1}, \pm 0.1 \mathrm{MPa}$; for the displacement, $\pm 5 \mathrm{~mm}$; and for strain, $\pm 0.5 \%$. 


\section{Results}

\section{Porosity and density}

Porosity and density values are given in Table 1 . Because the granodiorite was a fairly homogeneous material, both test samples gave similar values of around $1 \%$ porosity, a dry density of 2.64 to $2.65 \mathrm{~g} / \mathrm{cc}$, and a wet density (assuming the pores are filled with water) of around 2.65 to $2.66 \mathrm{~g} / \mathrm{cc}$. There was considerable sample variability in the diorite, causing porosity to range from 0.6 to $1.0 \%$, dry density from 2.81 to 2.88 $\mathrm{g} / \mathrm{cc}$, and wet density from 2.82 to $2.89 \mathrm{~g} / \mathrm{cc}$.

\section{Strength}

Differential stress (measured load minus confining pressure) versus axial displacement is shown at the five desired pressure conditions for the granodiorite and diorite samples (Figure 1). For the granodiorite, the failure stress increased in a systematic way with pressure, consistent with the overall homogeneity of the rock. Most samples experienced a total stress drop after failure. Friction sliding on the newly fractured surface stabilized quickly for the $13 \mathrm{MPa}$ run, but required more than a millimeter of displacement to evolve at the higher confining pressures.

The diorite samples were overall weaker than the granodiorites (Figure 1b), as well as being less systematic in their failure strength, owing to considerable sample heterogeneity. For instance, at confining pressures of 26 and 78.2 MPa the failure strength was markedly low relative to the trend of the other pressure runs. In addition, the stress drops were not total at these two confining pressures. Residual strength of the diorites stabilized quickly, with the exception of the sample at 52.1 MPa. Peak failure stress versus confining pressure (Figure 2 and Table 2) illustrates these failure trends for the two rock types.

Fracture angles for all samples ranged from 16 to $25^{\circ}$ measured from the vertical axis. In cases where more than one fracture formed, the principle fracture angle was recorded. From these angles and the recorded stresses of each sample, the shear and normal stress at failure resolved on the fracture surface and the coefficient of friction can be determined by the relations

$$
\begin{aligned}
& \sigma_{\Delta}=\text { axial load }-\mathrm{P}_{\mathrm{c}} \\
& \theta=\text { fracture angle } \\
& \tau=\left(\sigma_{\Delta} / 2\right)(\sin (2 \theta)) \\
& \sigma_{\mathrm{n}}=\mathrm{P}_{\mathrm{c}}+\left(\sigma_{\Delta} / 2\right)(1-\cos (2 \theta)) \\
& \mu=\tau / \sigma_{\mathrm{n}} .
\end{aligned}
$$

where $\sigma_{\Delta}$ is the differential stress, $\mathrm{P}_{\mathrm{c}}$ is the confining pressure, $\tau$ and $\sigma_{\mathrm{n}}$ are the shear and normal stresses respectively and $\mu$ is the coefficient of friction. Failure data are listed in Table 2.

From equations (5) and (6), we can construct Mohr's circle diagrams (Figure 3) for the granodiorite and diorite samples. The systematic trend of failure in the granodiorite (Figure 3a) clearly contrasts with the uneven spacing of the Mohr's circles for the diorite samples (Figure $3 b$ ) due to the less systematic failure of the diorites. The 
tangent to these circles give the failure envelopes for each rock type, which we show in Figure 4 using data from Figure 3 at an enlarged scale for clarity. The slope of the line is the coefficient of internal friction, $\mu_{\mathrm{i}}, 1.32$ for the granodiorite and 1.29 for the diorite. The $\mathrm{Y}$ intercept gives cohesion, $\mathrm{C}_{0}, 46.5 \mathrm{MPa}$ for the granodiorite and $31.9 \mathrm{MPa}$ for the diorite. Using equations (6) and (7) gives the angle of internal friction, $\phi_{i}$, and produce similar values of $52.8^{\circ}$ and $52.3^{\circ}$ for the granodiorite and diorite, respectively (Table 2 ). The two anomalously low-strength diorites were not included in these calculations.

In addition, the residual coefficient of friction at $5 \mathrm{~mm}$ of displacement was calculated (Table 3). These values represent the rock-on-rock coefficient of friction of the fractured surfaces. Values ranged from 0.81 to 1.19 for the granodiorite and 0.73 to 0.90 for the diorite, a bit higher than typical values from Byerlee's Law of 0.6 to 0.85 . It should be noted that some samples fractured along surfaces that intersected the steel endplugs. In this case, calculation of residual friction will be too high since part of the shear stress is still supported by intact rock.

Although these tests were conducted at room temperature, strength results of Coso samples obtained by TerraTek (unpublished data) indicate little sensitivity of dry strength to temperature in the range of temperatures reasonable for the Coso Geothermal Field.

\section{Elastic properties}

Elastic properties were determined from tests run at the two highest confining pressures of 52.1 and 78.2 according to the following relations:

$\begin{array}{ll}\text { Bulk Modulus } & \mathrm{B}=\Delta \mathrm{P}_{\mathrm{c}} / \Delta \varepsilon_{\mathrm{vol}}=\Delta \mathrm{P}_{\mathrm{c}} /\left(\Delta \varepsilon_{\mathrm{ax}}+2 \Delta \varepsilon_{\mathrm{t}}\right) \\ \text { Young's Modulus } & \mathrm{E}=\sigma_{1} / \varepsilon_{\mathrm{ax}} \\ \text { Poisson's Ratio } & \mathrm{U}=\Delta \varepsilon_{\mathrm{t}} / \Delta \varepsilon_{\mathrm{ax}} \\ \text { Stiffness } & \mathrm{k}=\sigma_{1} / \Delta \mathrm{l}\end{array}$

where $\mathrm{P}_{\mathrm{c}}$ is confining pressure, $\varepsilon_{\mathrm{vol}}$ is volumetric strain, $\varepsilon_{\mathrm{ax}}$ is axial strain, $\varepsilon_{\mathrm{t}}$ is transverse strain, $\sigma_{1}$ is axial stress and $l$ is the length of the sample. Bulk modulus, the change in confining pressure with change in volumetric strain, was determined from the $10 \mathrm{MPa}$ unloading and subsequent reloading of the confining pressure, which generally had a different slope than the initial pressure loading curve. For calculations of Young's Modulus, the change in differential stress with axial strain; Poisson's Ratio, the change in axial strain with transverse strain; and Stiffness, the change in stress with displacement, the $100 \mathrm{MPa}$ unloading and reloading of the differential stress was used. These curves also displayed a different slope than the initial stress loading curve. All these data are shown for the granodiorite in Figures 5a-c and 6a-c, and for the diorite in Figures 7a-c and 8a-c. Elastic properties, determined from equations 8-11, are given in Table 4. In addition, standard stress-strain curves are shown for the two rock types in Figures $5 \mathrm{~d}-8 \mathrm{~d}$. In these plots, the failure stress (determined in a subsequent experiment), is included as a single data point for comparison. The axial strain at failure was estimated from the known displacement at failure and the slope of the loading curves before pressure cycling.

Summarizing the strain tests, we see that the Poisson's Ratio of the two rock types was fairly independent of pressure, at around 0.27 and 0.31 for the granodiorite and diorite, respectively. Other elastic properties (Bulk Modulus, Young's Modulus and 
Sample Stiffness) were pressure dependent, although not always in a consistent manner in the diorite samples. Also, the diorite samples had uniformly higher values for each of the elastic properties than the granodiorite. 
Table 1. Porosity and Density

Sample volume, dry weight, wet weight, porosity, $\Phi$ dry density, wet density,

\begin{tabular}{|c|c|c|c|c|c|c|}
\hline $\begin{array}{c}\text { granodiorite } \\
\text { B3R3 1c }\end{array}$ & 13.13 & 34.688 & 21.694 & 0.010 & 2.642 & 2.652 \\
\hline B3R3 1c & 12.71 & 33.745 & 21.162 & 0.010 & 2.654 & 2.664 \\
\hline $\begin{array}{c}\text { diorite } \\
\text { B1R1 1f }\end{array}$ & 13.06 & 37.699 & 24.711 & 0.006 & 2.886 & 2.892 \\
\hline B1R1 1f & 11.80 & 33.228 & 21.535 & 0.010 & 2.815 & 2.825 \\
\hline
\end{tabular}

Table 2. Failure Data

\begin{tabular}{|c|c|c|c|c|c|c|c|c|c|}
\hline Sample & $\begin{array}{r}\mathrm{P}_{\mathrm{C}} \\
\mathrm{MPa}\end{array}$ & $\begin{array}{c}\sigma_{1}, \mathrm{MPa} \\
\text { Peak }\end{array}$ & $\begin{array}{c}\sigma_{\Delta}, \mathrm{MPa} \\
\text { Peak }\end{array}$ & $\begin{array}{l}\text { sample } \\
\text { failure } \\
\text { angle, }\end{array}$ & $\begin{array}{r}\sigma_{n} \\
\mathrm{MPa}\end{array}$ & $\begin{array}{c}\tau, \\
\mathrm{MPa}\end{array}$ & $\begin{array}{l}\mu_{\mathrm{i},} \\
\text { inter- } \\
\text { nal }\end{array}$ & \begin{tabular}{l}
\multicolumn{1}{c}{$\phi_{\mathrm{i}}}$, \\
internal \\
failure \\
angle, $^{\circ}$
\end{tabular} & $\begin{array}{r}\mathrm{C}_{0} \\
\mathrm{MPa}\end{array}$ \\
\hline $\begin{array}{c}\text { granodiorite } \\
\text { B3R3 1b }\end{array}$ & 0.0 & 240.2 & 240.2 & 18 & 22.9 & 70.6 & & & \\
\hline B3R3 1c1 & 13.0 & 387.1 & 374.1 & 23 & 70.1 & 134.6 & & & \\
\hline B3R3 1c2 & 26.0 & 596.6 & 570.6 & 16 & 69.4 & 151.2 & & & \\
\hline B3R3 1b1 & 52.1 & 770.0 & 717.9 & 22 & 152.8 & 249.4 & & & \\
\hline \multirow[t]{2}{*}{ B3R3 1b2 } & 78.2 & 945.2 & 867.0 & 19 & 170.1 & 266.9 & & & \\
\hline & & & & & & & 1.32 & 52.8 & 46.5 \\
\hline $\begin{array}{c}\text { diorite } \\
\text { B1R1 1g1 }\end{array}$ & 0.0 & 186.0 & 186.0 & 18 & 17.8 & 54.7 & & & \\
\hline $\mathrm{B} 1 \mathrm{R} 1 \mathrm{gg} 2$ & 13.0 & 301.0 & 288.0 & 20 & 46.7 & 92.6 & & & \\
\hline B1R1 1g3 & 26.0 & 323.3 & 297.3 & 20 & 60.8 & 95.6 & & & \\
\hline B1R1 $1 \mathrm{f} 1$ & 52.1 & 633.9 & 581.8 & 18 & 107.7 & 171.0 & & & \\
\hline \multirow[t]{2}{*}{$\mathrm{B} 1 \mathrm{R} 1 \mathrm{ff} 2$} & 78.2 & 581.8 & 503.6 & 25 & 168.2 & 192.9 & & & \\
\hline & & & & & & & 1.29 & 52.3 & 31.9 \\
\hline
\end{tabular}


Table 3. Stresses and Residual Friction at $5 \mathrm{~mm}$ Displacement

\begin{tabular}{|c|c|c|c|c|c|}
\hline Sample & $\mathrm{P}_{\mathrm{C}}, \mathrm{MPa}$ & $\sigma_{\Delta}, \mathrm{MPa}$ & $\tau, \mathrm{MPa}$ & $\sigma_{\mathrm{n}}, \mathrm{MPa}$ & $\mu$ residual \\
\hline $\begin{array}{c}\text { granodiorite } \\
\text { B3R3 1c1 }\end{array}$ & 13.0 & 88.2 & 31.7 & 26.5 & 1.20 \\
\hline B3R3 1C2 & 26.0 & 131.6 & 34.9 & 36.0 & 0.97 \\
\hline B3R3 1b1 & 52.1 & 269.5 & 93.6 & 89.9 & 1.04 \\
\hline B3R3 1b2 & 78.2 & 285.7 & 88.0 & 108.5 & 0.81 \\
\hline $\begin{array}{c}\text { diorite } \\
\text { B1R1 1g2 }\end{array}$ & 13.0 & 54.8 & 17.6 & 19.4 & 0.91 \\
\hline B1R1 1g3 & 26.0 & 87.4 & 28.1 & 36.2 & 0.76 \\
\hline B1R1 1f1 & 52.1 & 182.1 & 53.5 & 69.5 & 0.77 \\
\hline B1R1 1f2 & 78.2 & 252.7 & 96.8 & 132.3 & 0.73 \\
\hline
\end{tabular}

Table 4. Elastic Properties

\begin{tabular}{|c|c|c|c|c|c|}
\hline Sample & $\mathrm{P}_{\mathrm{C}}, \mathrm{MPa}$ & $\begin{array}{l}\text { Poisson's } \\
\text { Ratio } \\
\end{array}$ & $\begin{array}{c}\text { Bulk Modulus, } \\
\text { GPa }\end{array}$ & $\begin{array}{c}\text { Young's } \\
\text { Modulus, GPa }\end{array}$ & $\begin{array}{l}\text { Stiffness, } \\
\mathrm{MPa} / \mathrm{mm}\end{array}$ \\
\hline $\begin{array}{c}\text { granodiorite } \\
\text { B3R3 1b1 }\end{array}$ & 52.1 & 0.277 & 26.9 & 74.1 & 1314 \\
\hline B3R31b2 & 78.2 & 0.270 & 36.2 & 75.4 & 1342 \\
\hline $\begin{array}{c}\text { diorite } \\
\text { B1R1 1f1 }\end{array}$ & 52.1 & 0.311 & 49.1 & 105.1 & 1880 \\
\hline $\mathrm{B} 1 \mathrm{R} 1 \mathrm{ff} 2$ & 78.2 & 0.313 & 53.8 & 100.7 & 1778 \\
\hline
\end{tabular}




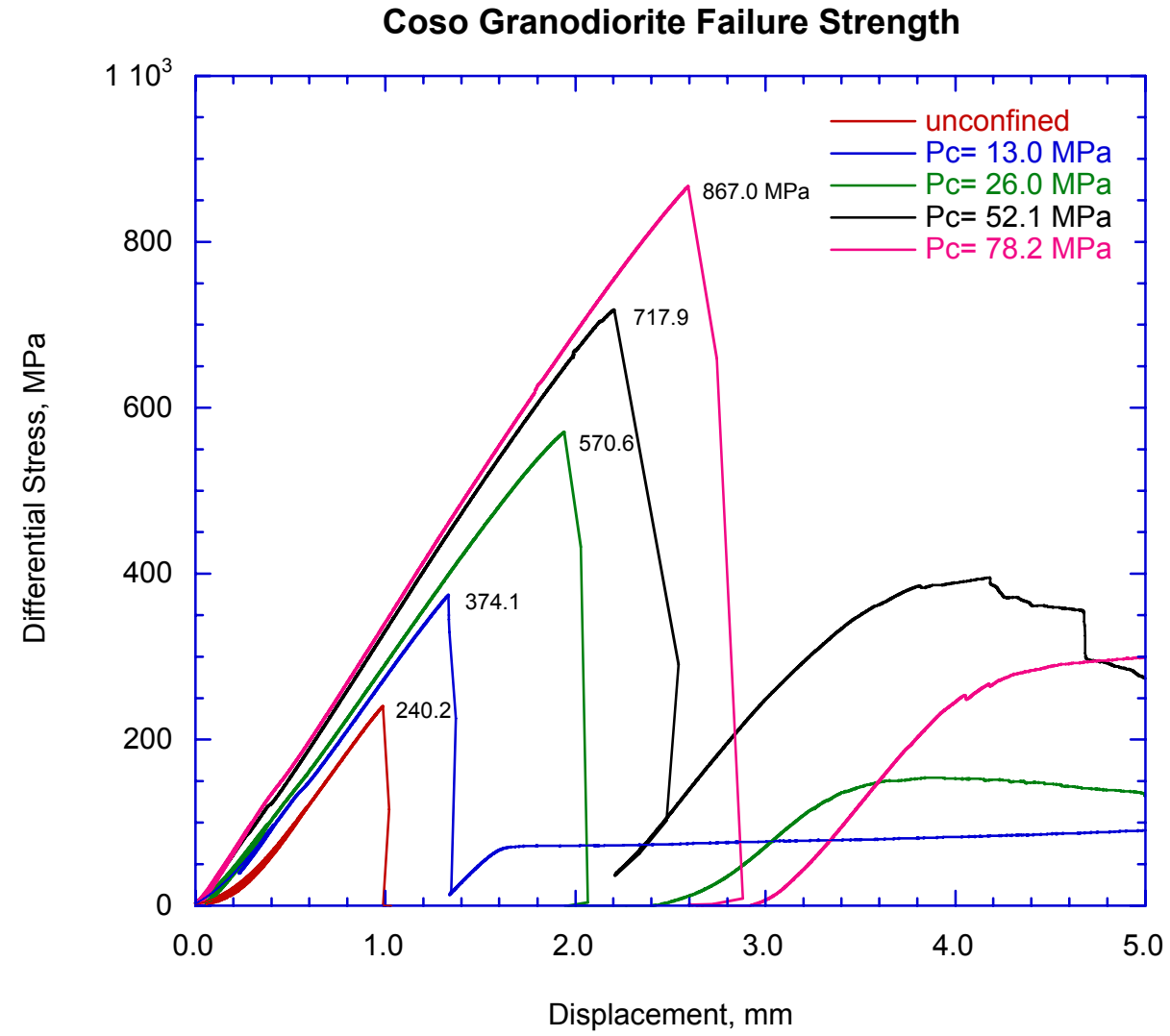

Figure 1. Differential stress as a function of axial displacement for (a) granodiorite samples from a depth of $8406 \mathrm{ft}$, and (b) diorites from a depth of $7974 \mathrm{ft}$. 


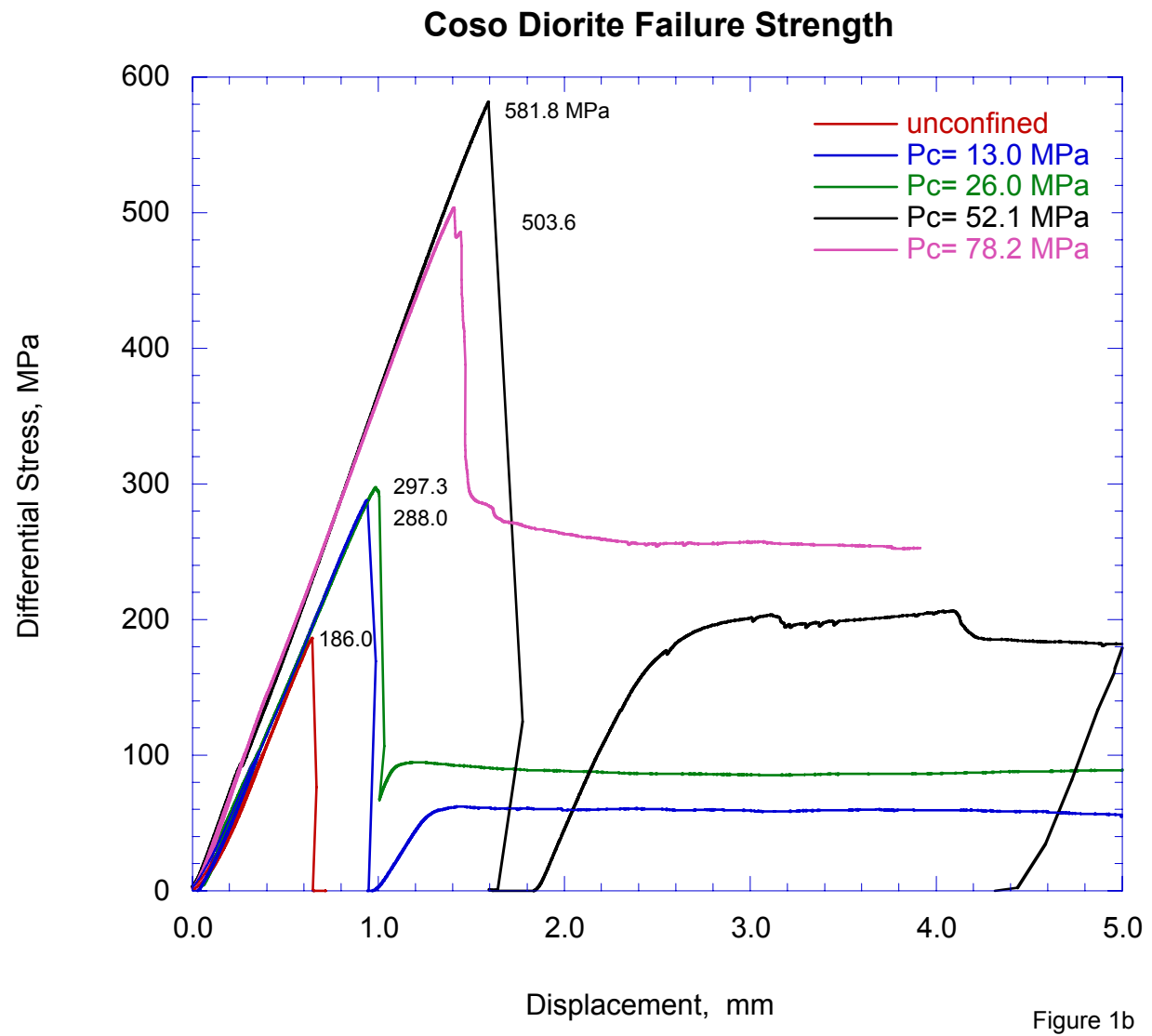




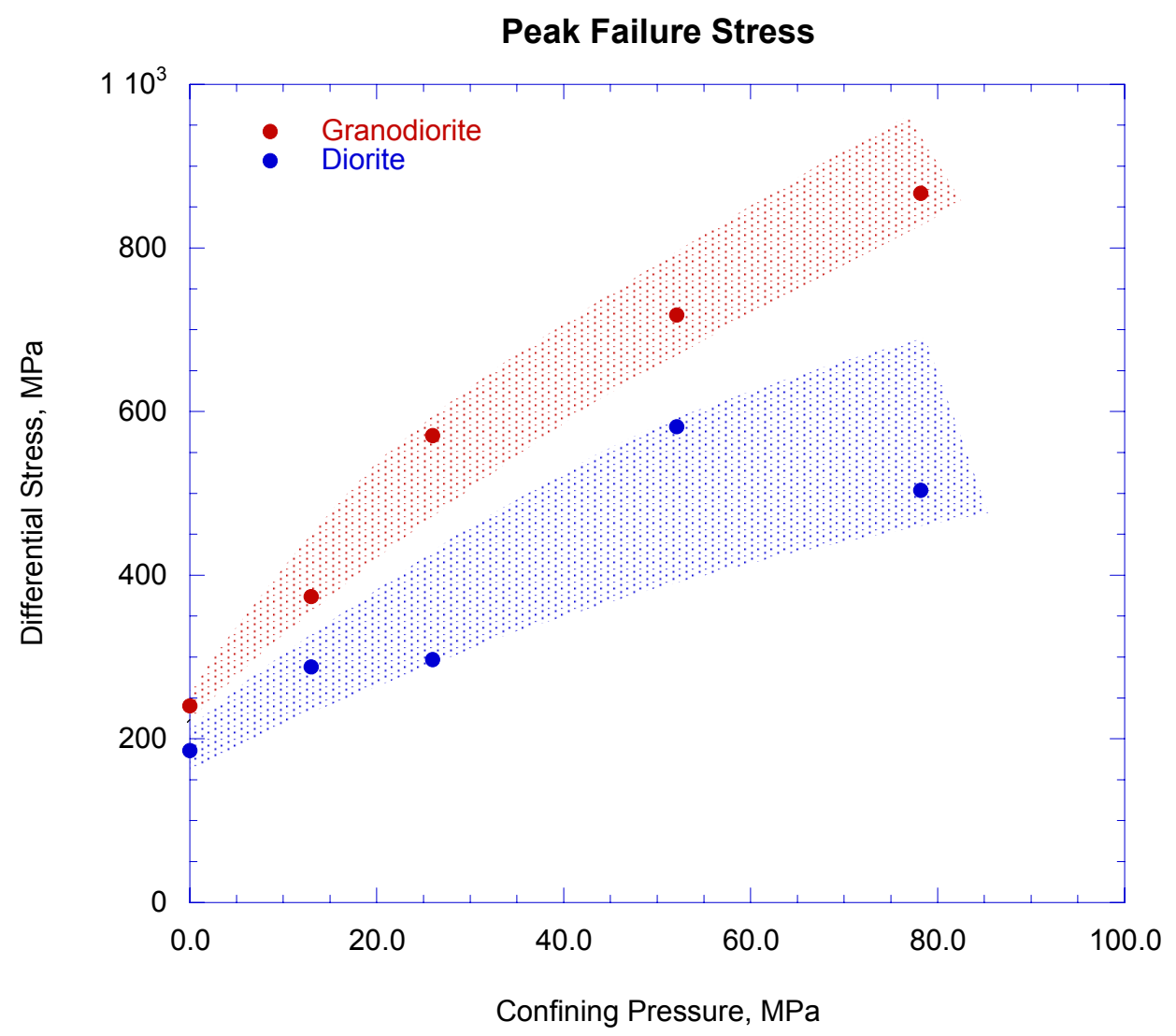

Figure 2

Figure 2. Peak failure stress of the granodiorites and diorites as a function of confining pressure. 


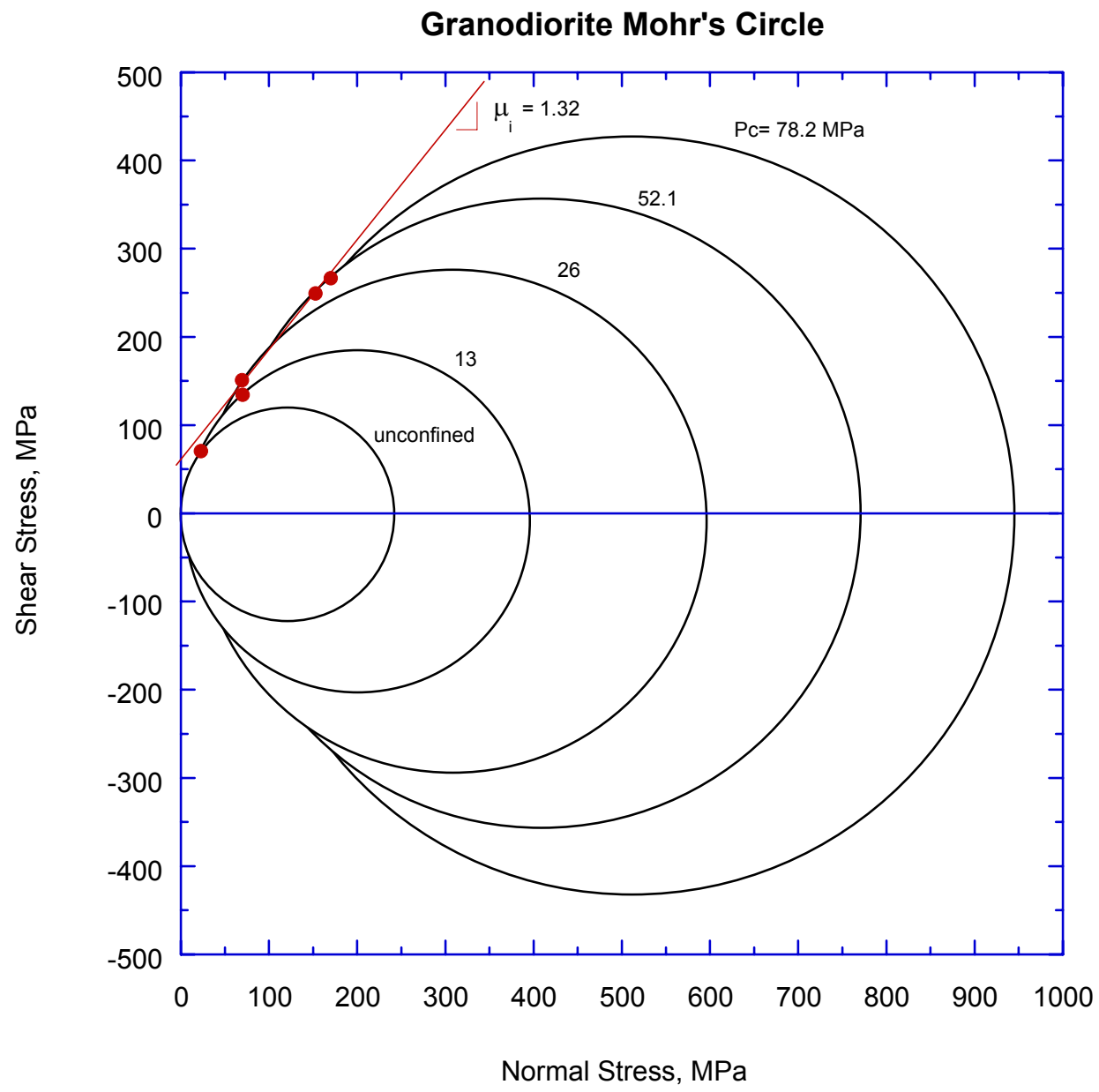

Figure 3a

Figure 3. Mohr's circle diagrams for (a) granodiorite samples and (b) diorites. Shear and normal stresses at failure (red data points) for each confining pressure are shown along the perimeter of the corresponding Mohr circle. 


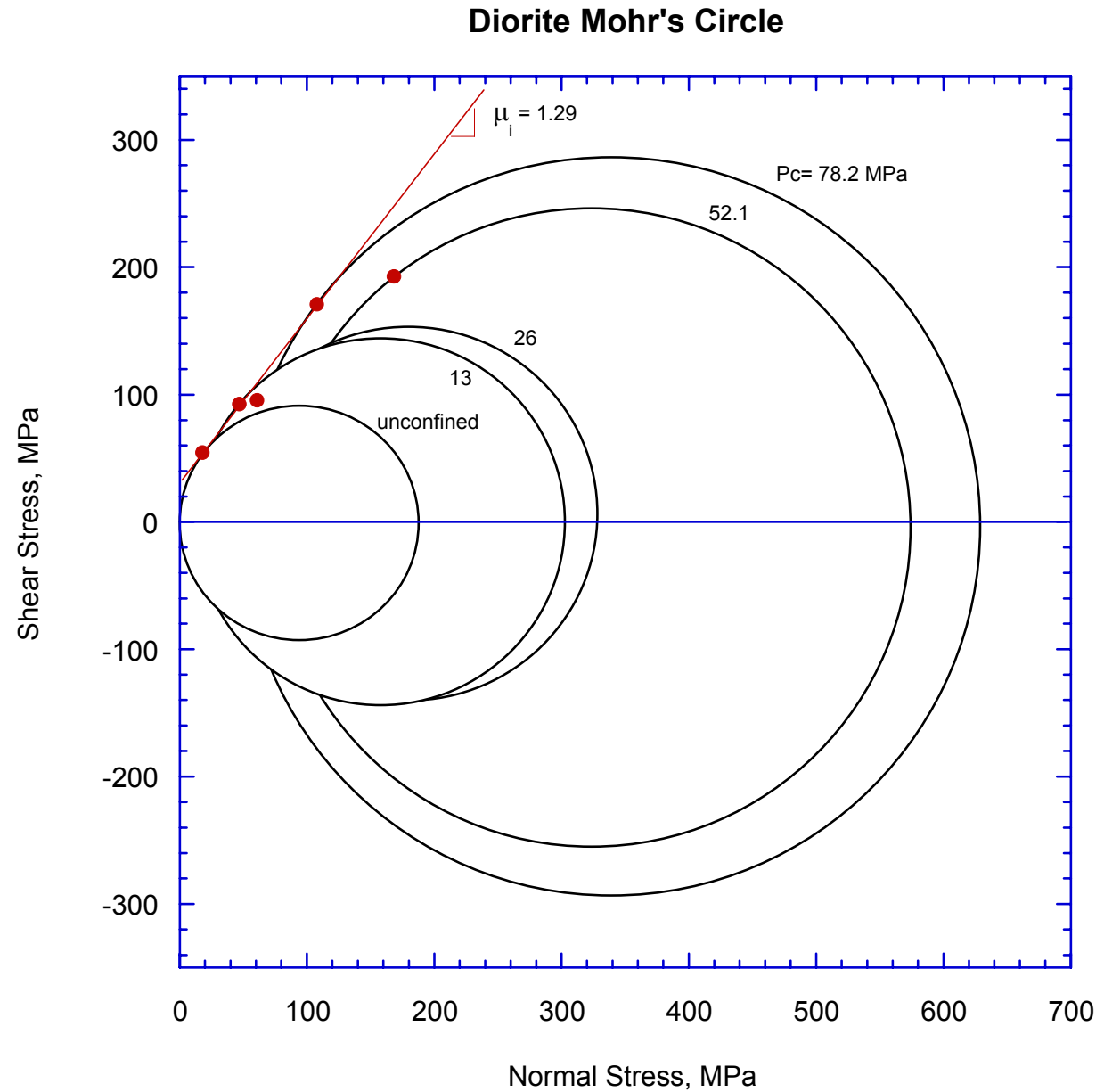

Figure $3 b$ 


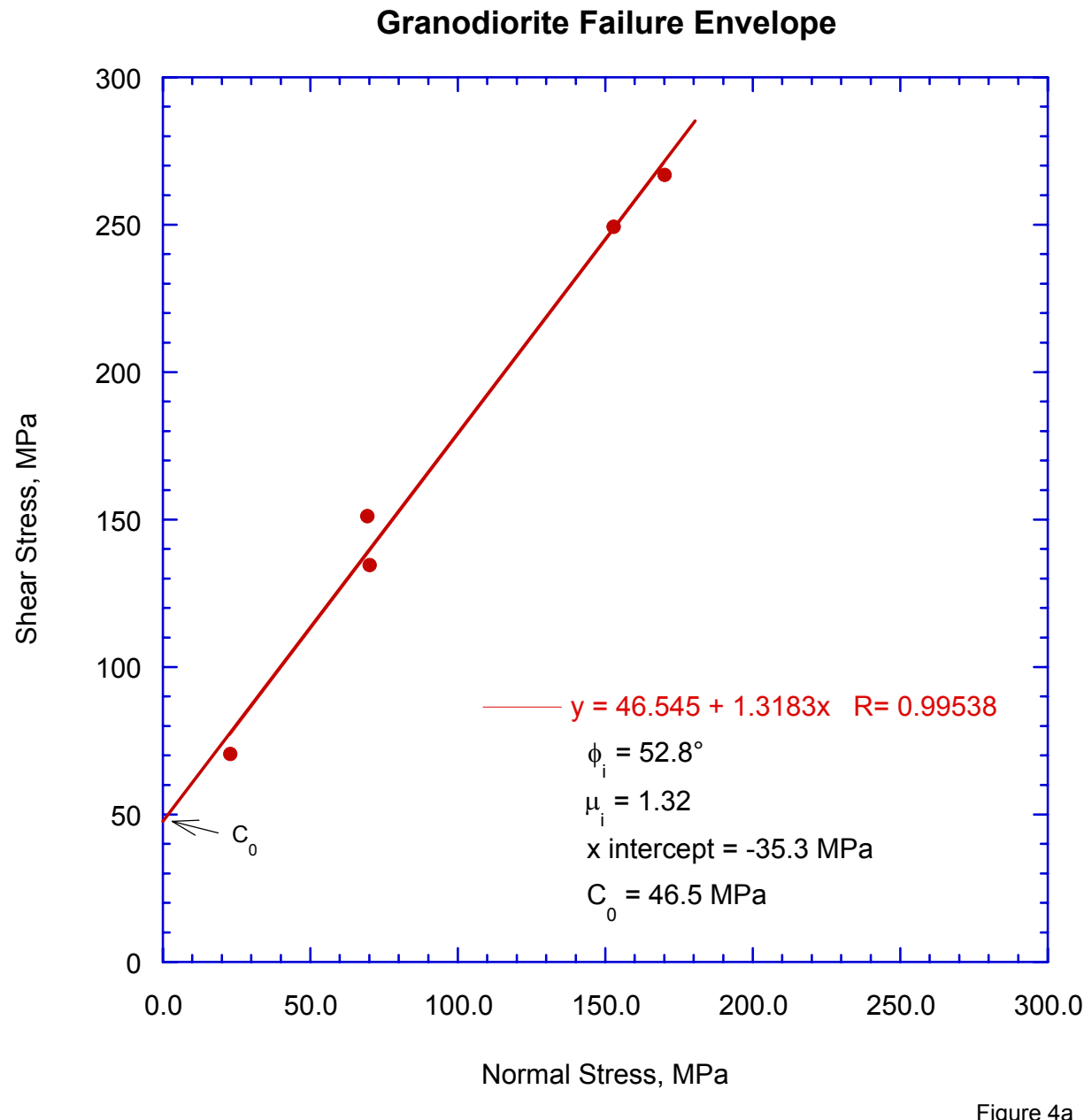

Figure 4. Failure envelopes for (a) granodiorites and (b) diorites. For the diorites, the two anomalously weak samples were excluded. 


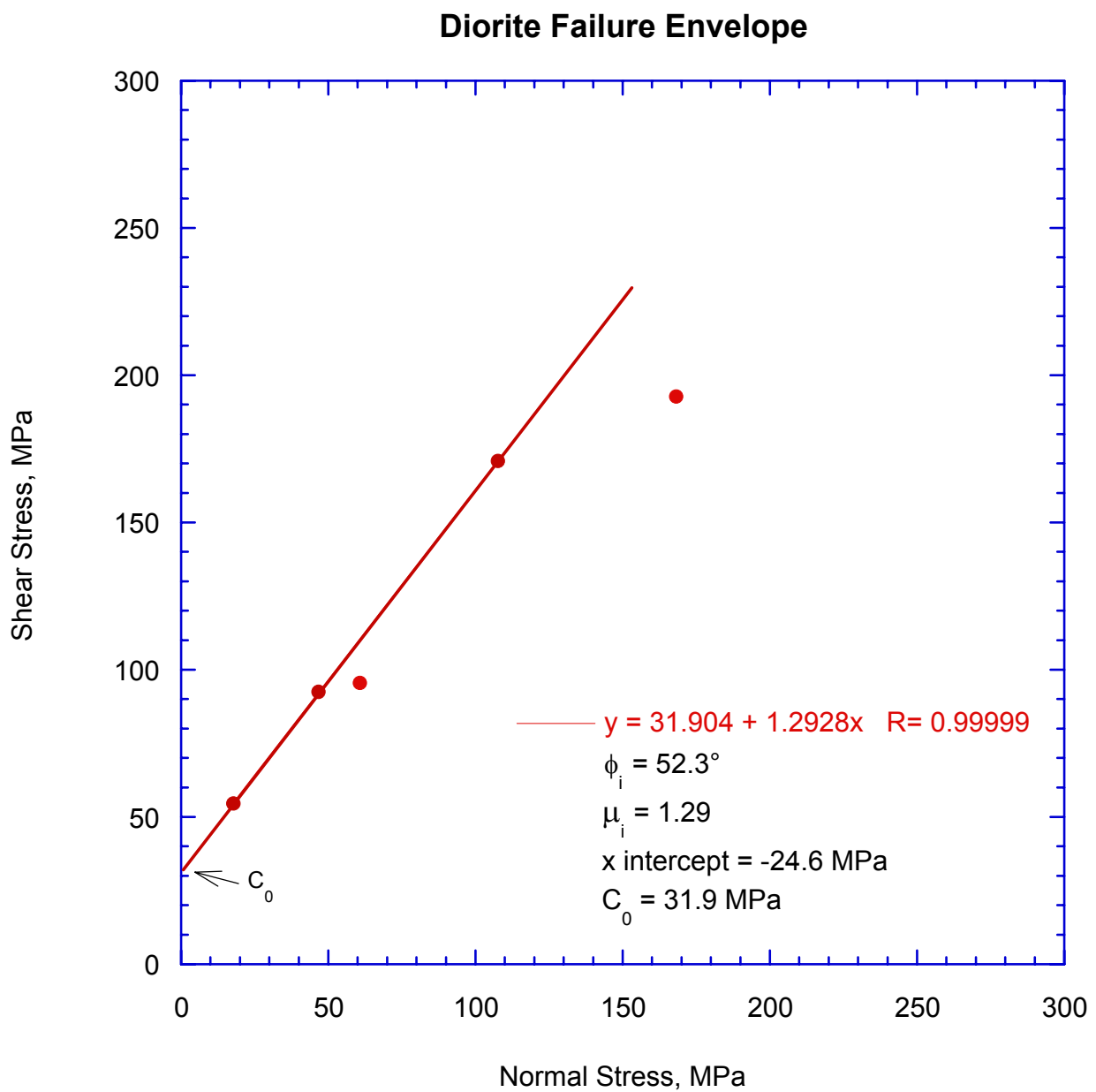

Figure 4b 


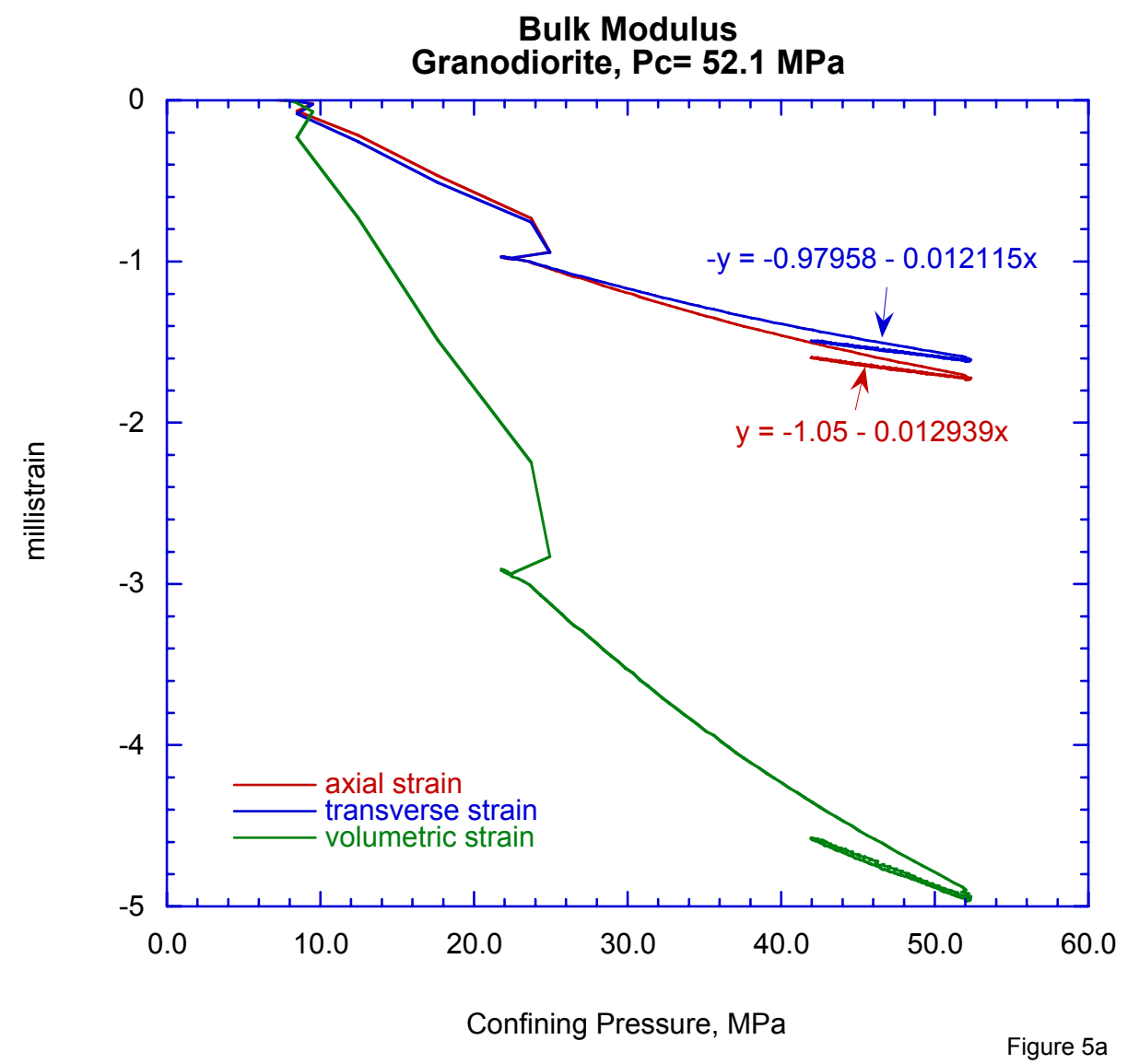

Figure 5. Strain data for the determination of elastic properties of the granodiorite at a confining pressure of 52.1 MPa: (a) Bulk Modulus, (b) Young's Modulus and Sample Stiffness, (c) Poisson's Ratio, and (d) the stress-strain relation, with the failure strength and estimated strain at failure shown as a single point. 


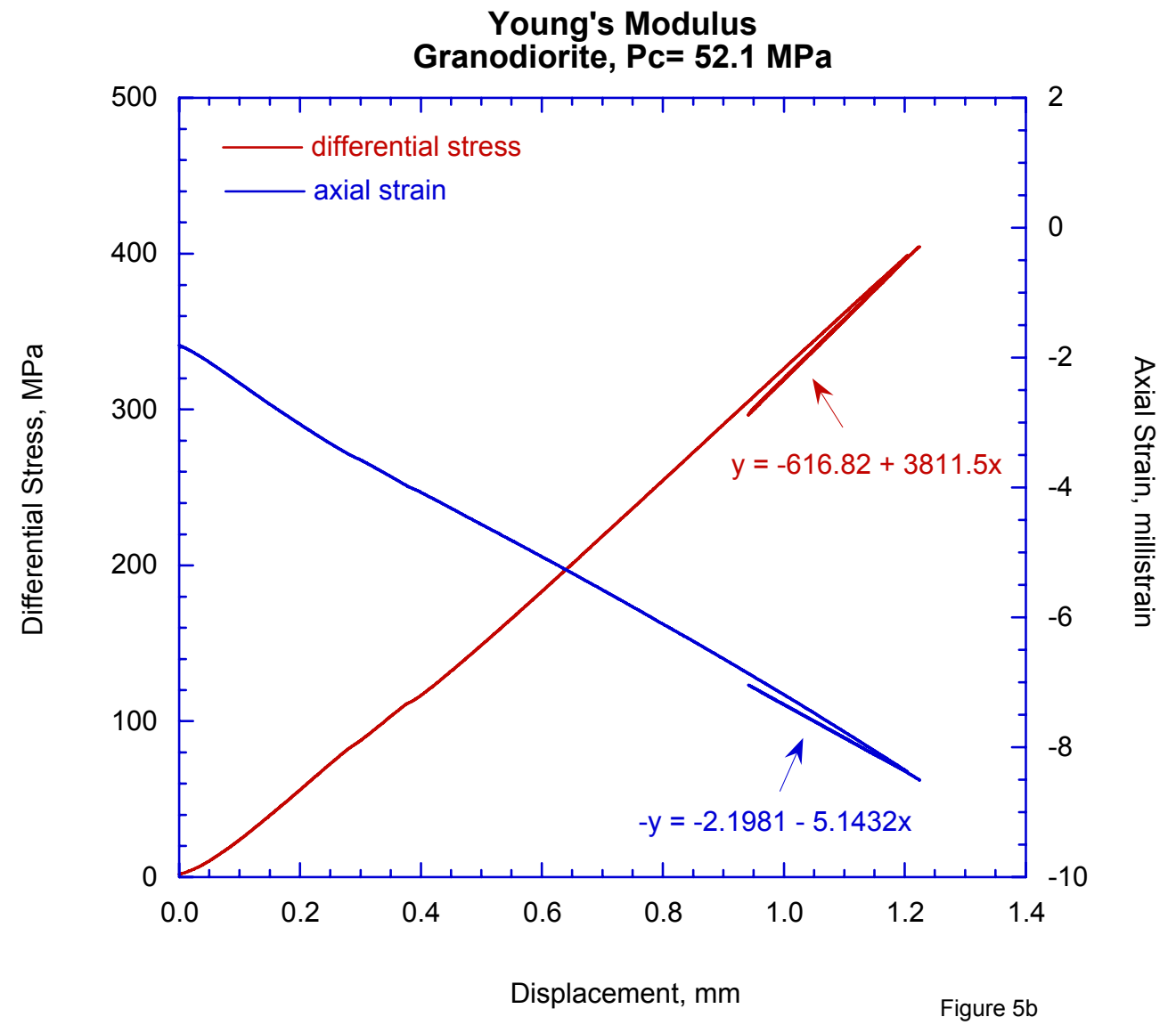




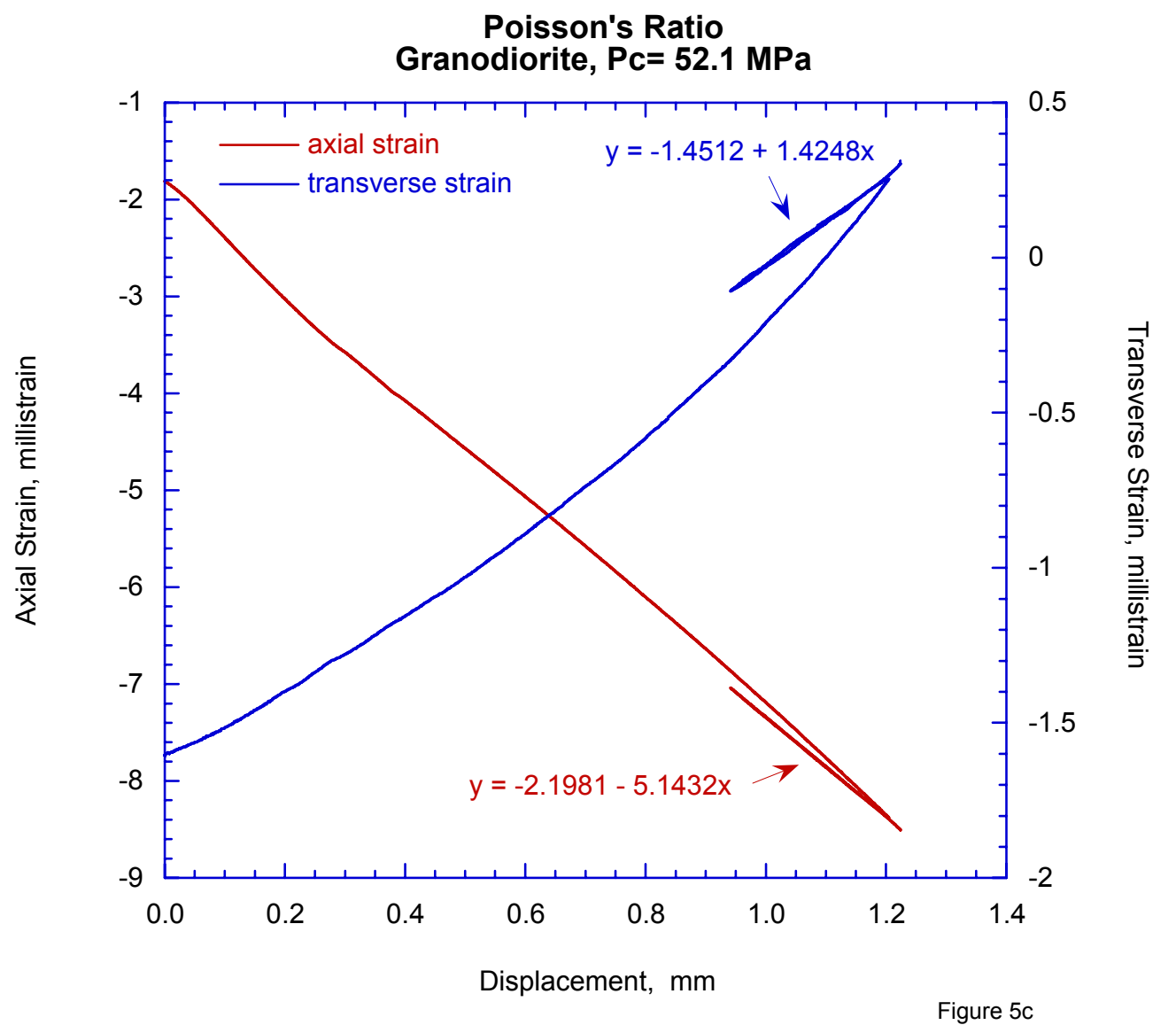




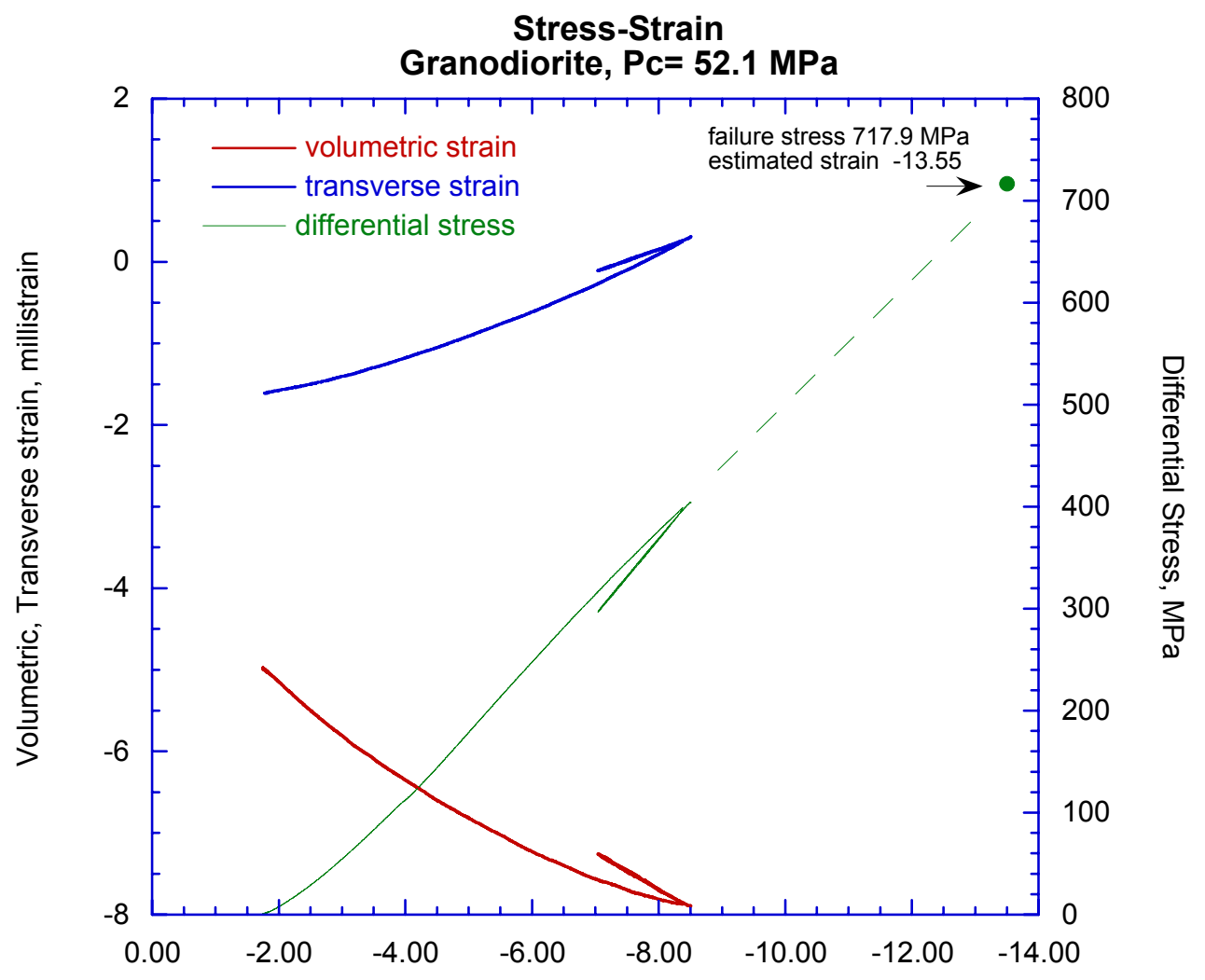

Axial Strain, millistrain

Figure 5d 


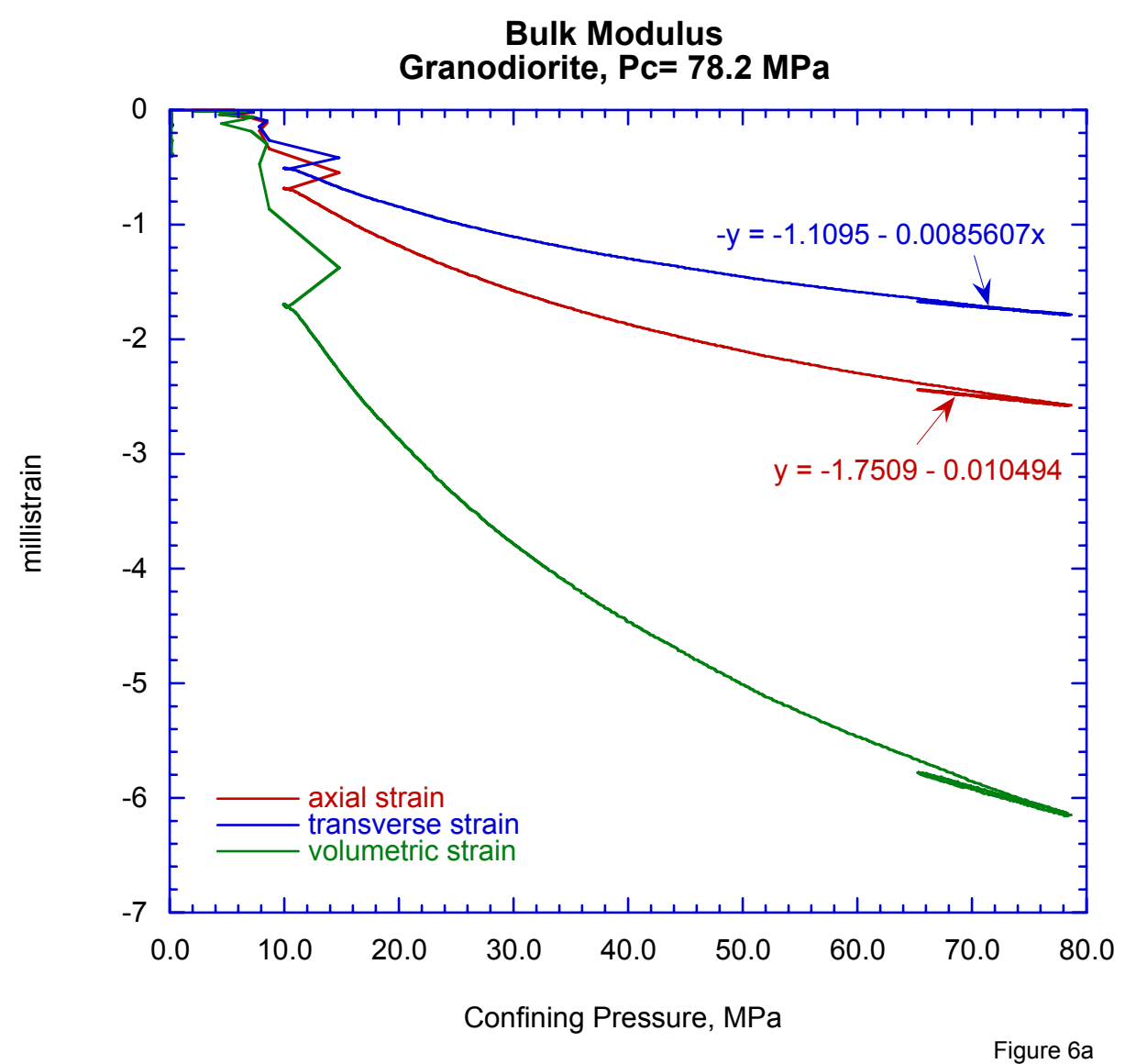

Figure 6. Strain data for the determination of elastic properties of the granodiorite at a confining pressure of 78.2 MPa: (a) Bulk Modulus, (b) Young's Modulus and Sample Stiffness, (c) Poisson's Ratio, and (d) the stress-strain relation, with the failure strength and estimated strain at failure shown as a single point. 


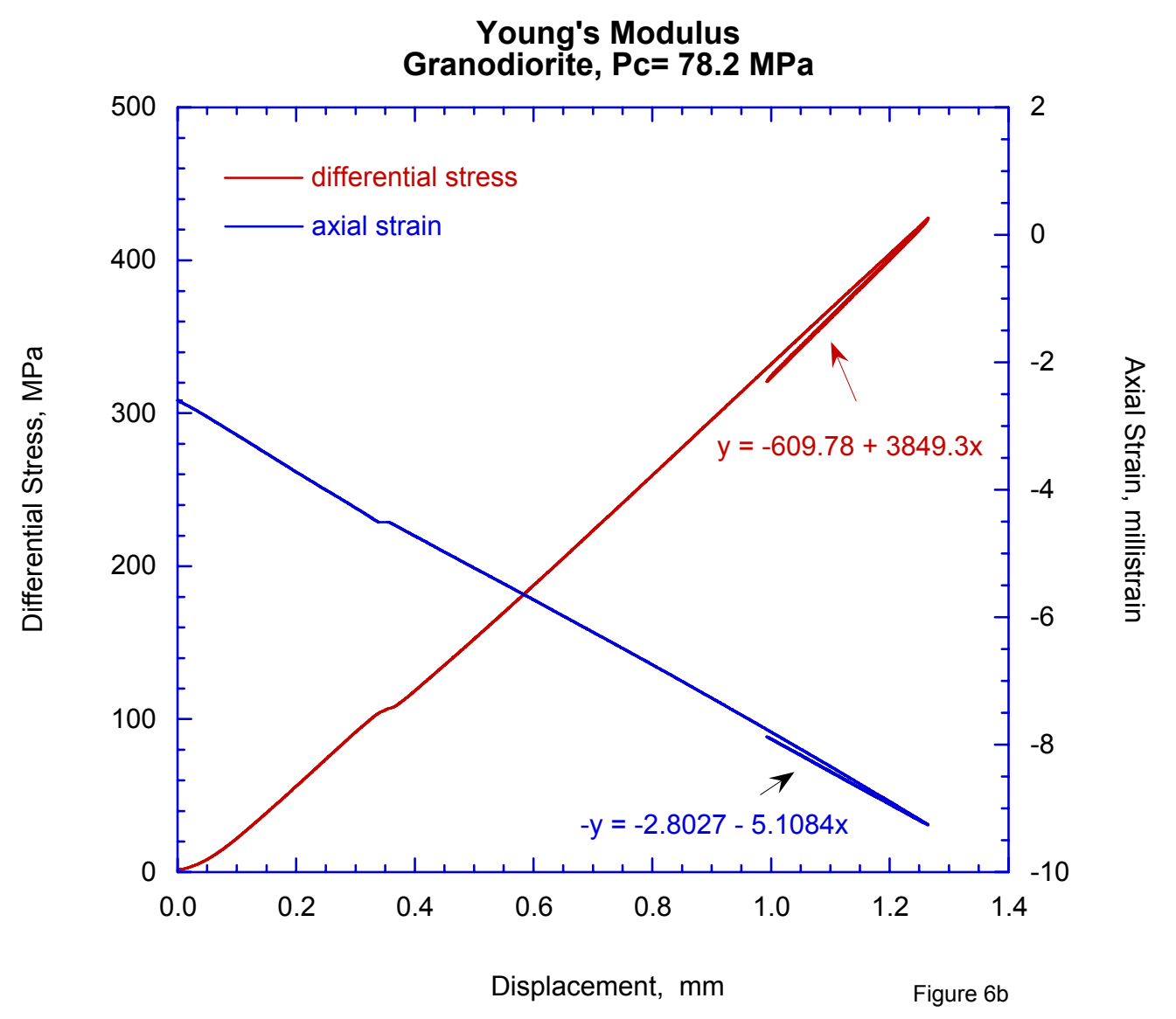




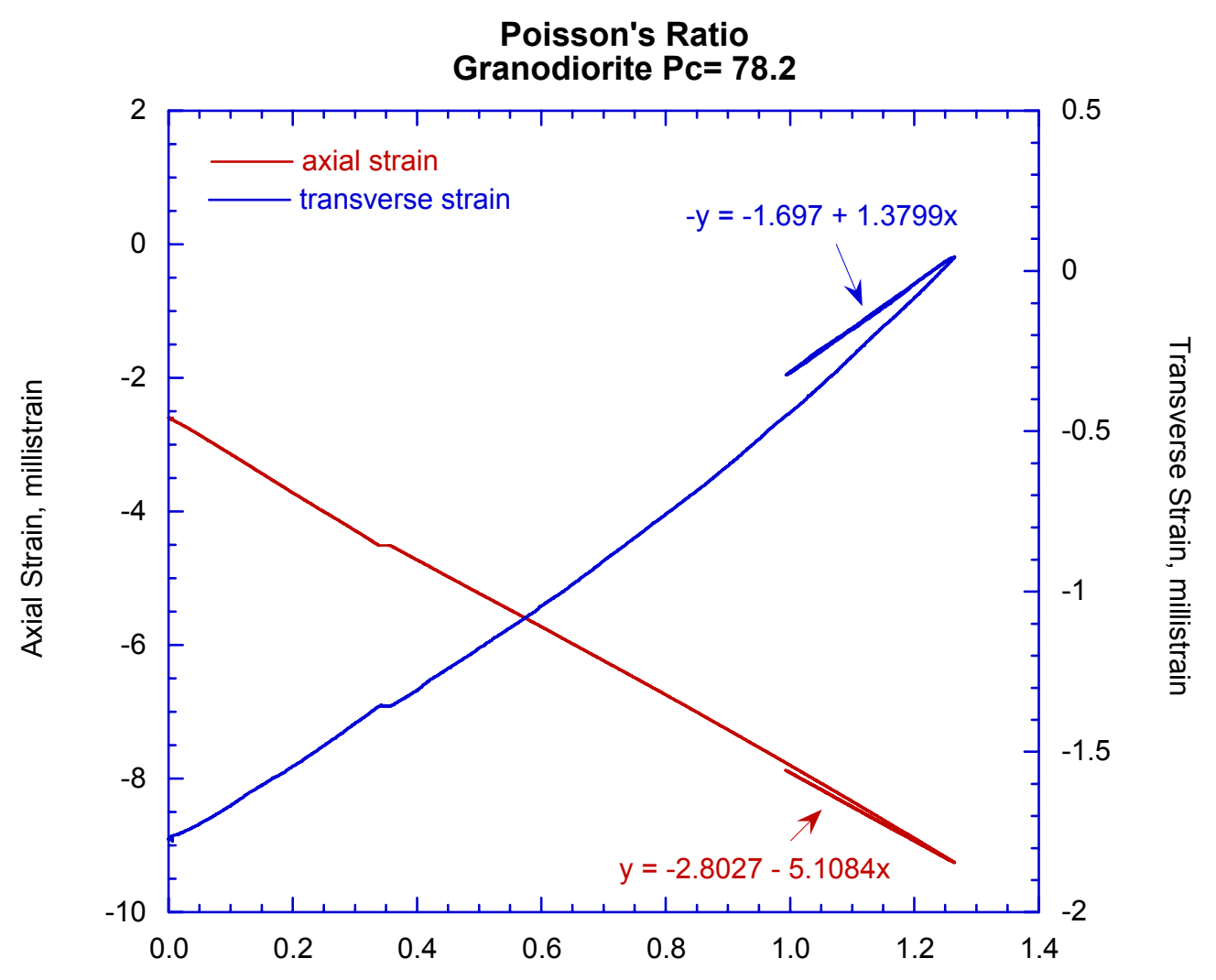

Displacement, $\mathrm{mm}$

Figure 6c 


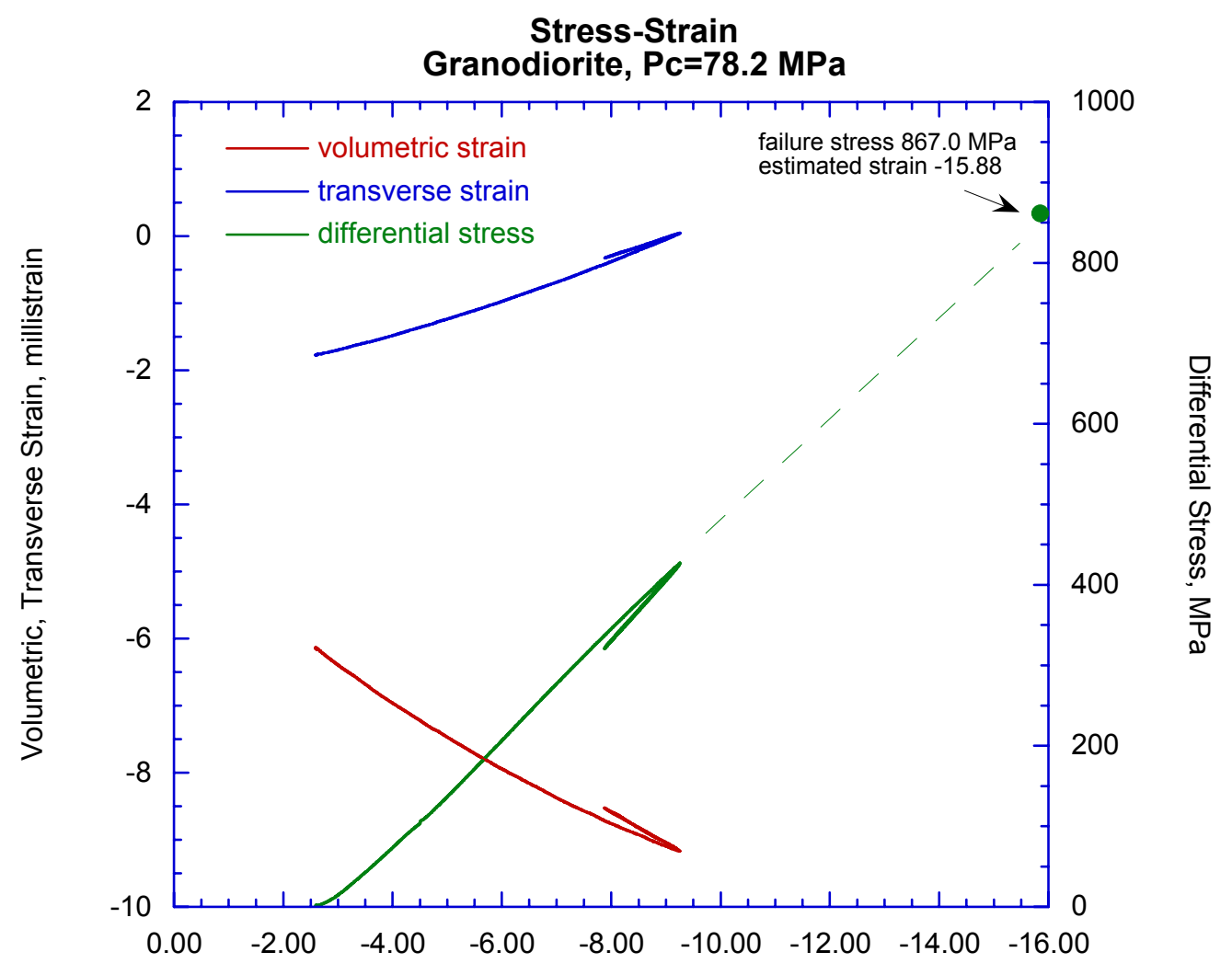

Axial Strain, millistrain

Figure 6d 


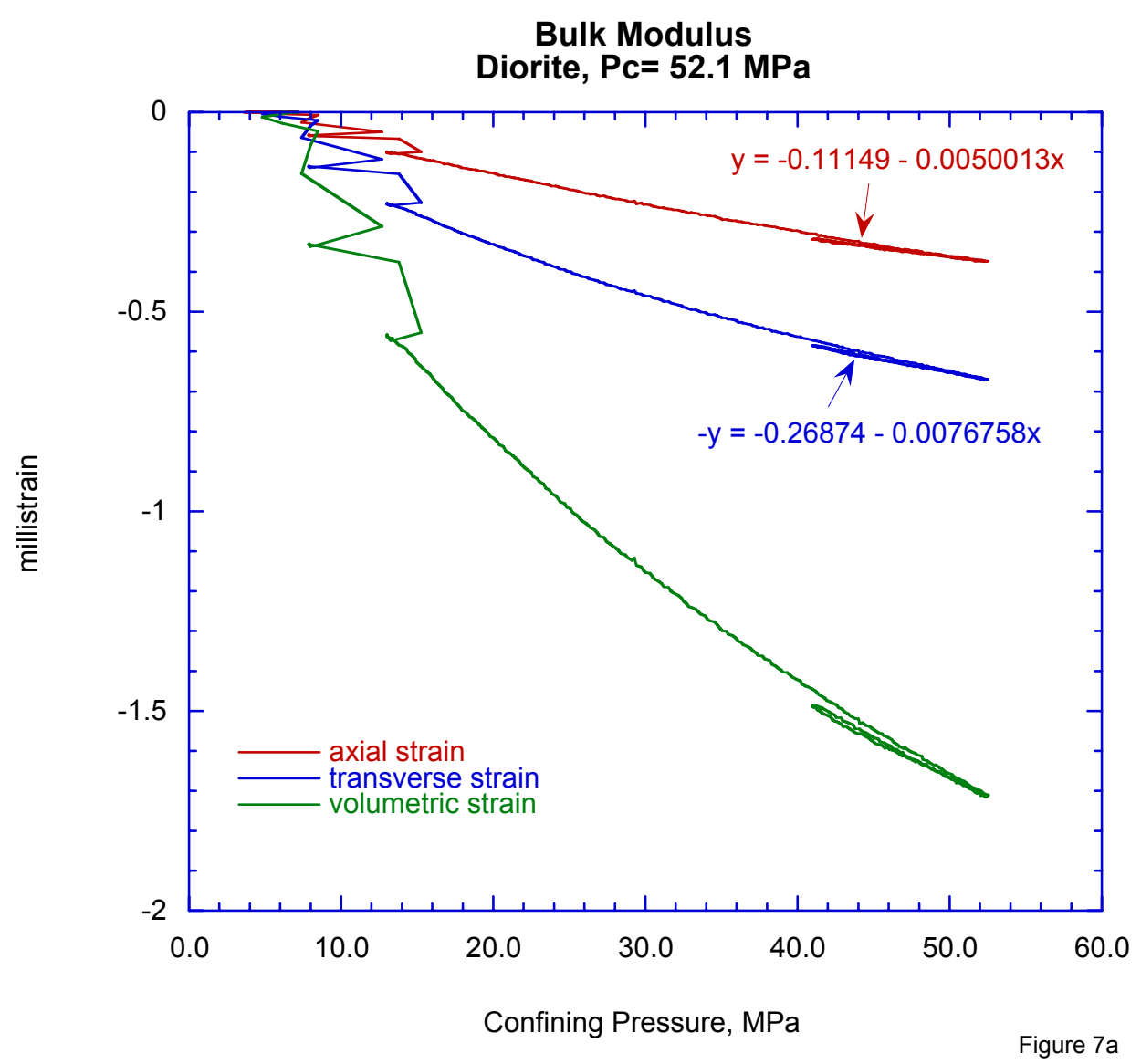

Figure 7. Strain data for the determination of elastic properties of the diorite at a confining pressure of 52.1 MPa: (a) Bulk Modulus, (b) Young's Modulus and Sample Stiffness, (c) Poisson's Ratio, and (d) the stress-strain relation, with the failure strength and estimated strain at failure shown as a single point. 


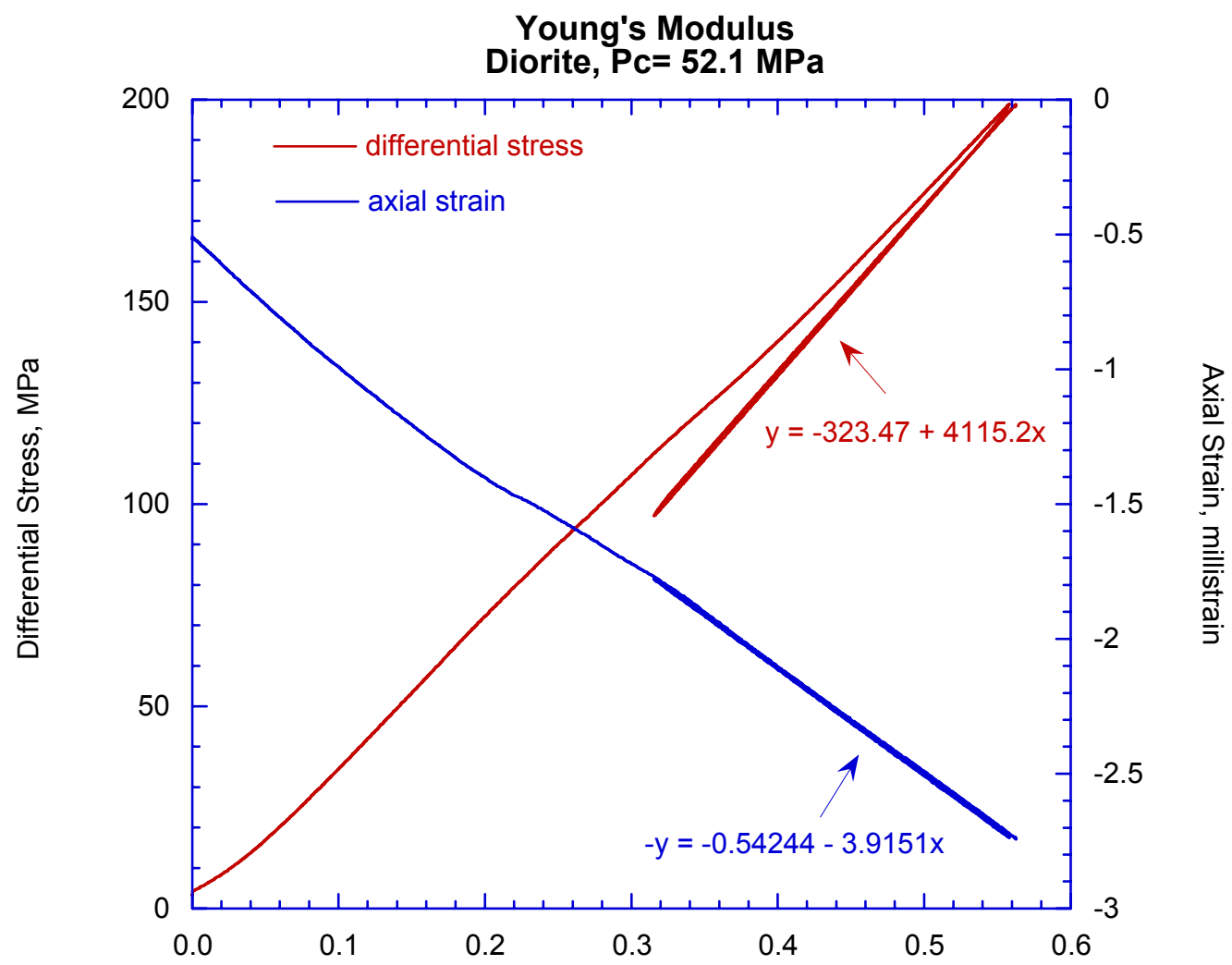

Displacement, mm

Figure 7b 


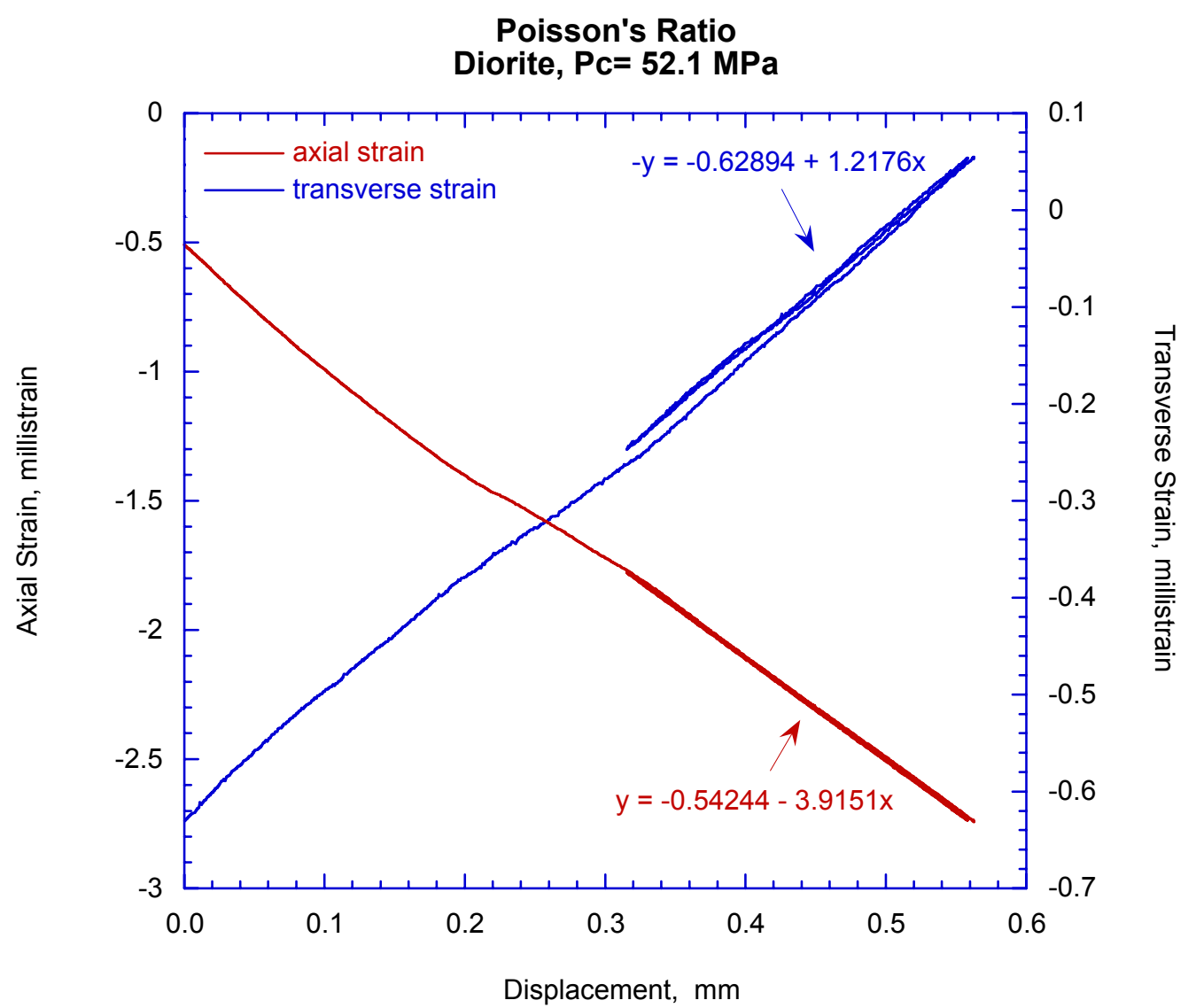

Figure 7c 


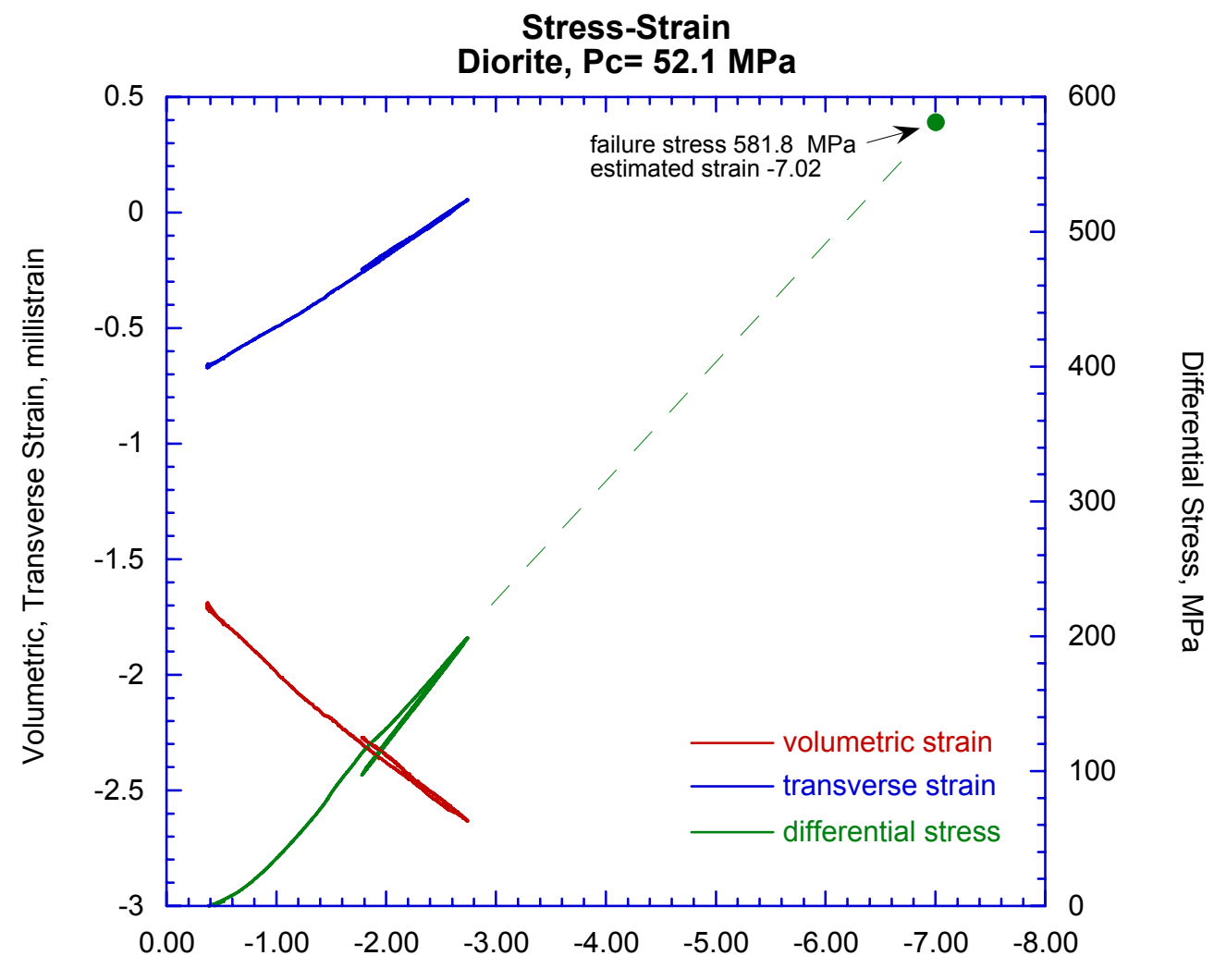

Axial Strain, millistrain 


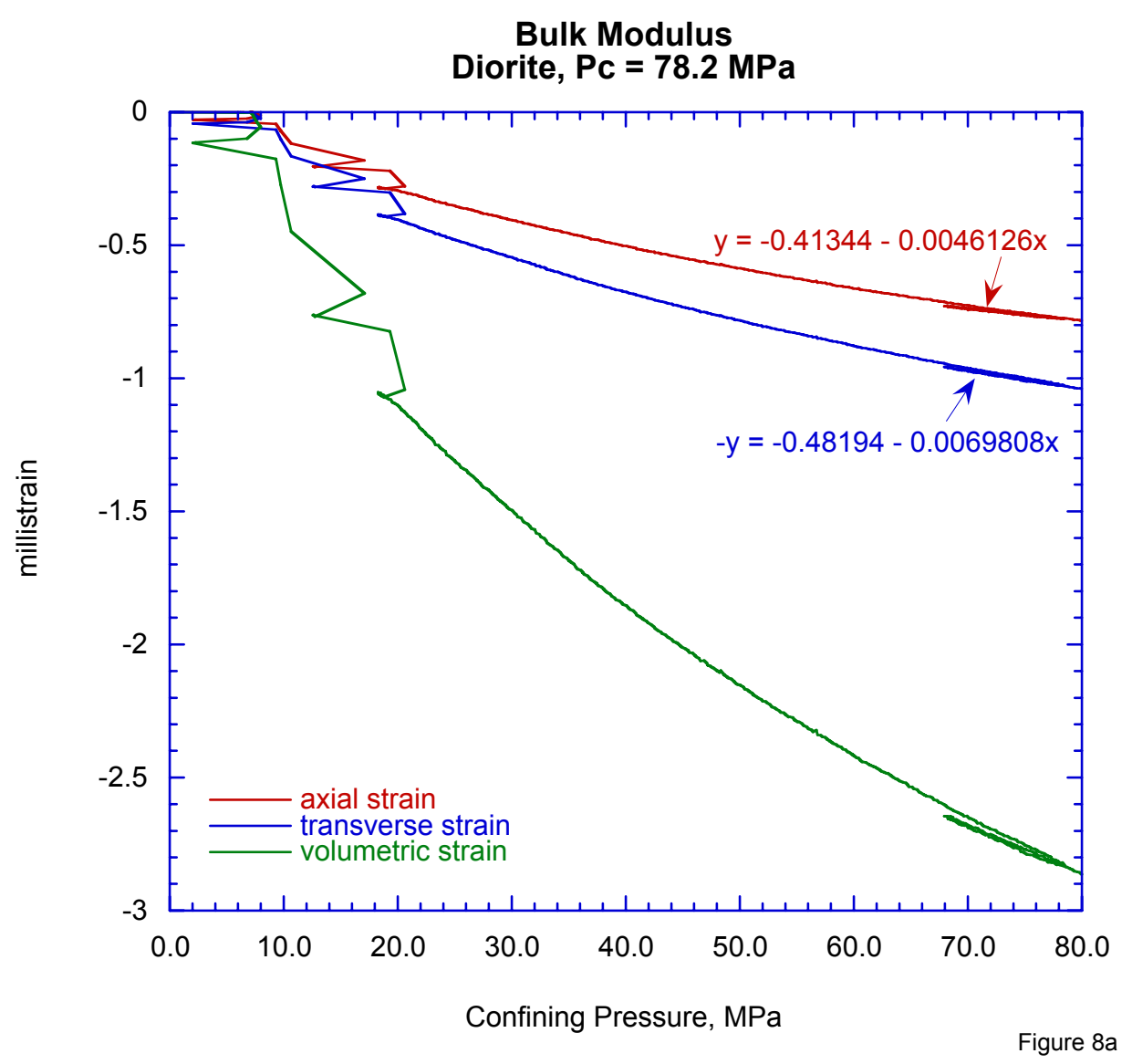

Figure 8. Strain data for the determination of elastic properties of the diorite at a confining pressure of 78.2 MPa: (a) Bulk Modulus, (b) Young's Modulus and Sample Stiffness, (c) Poisson's Ratio, and (d) the stress-strain relation, with the failure strength and estimated strain at failure shown as a single point. 


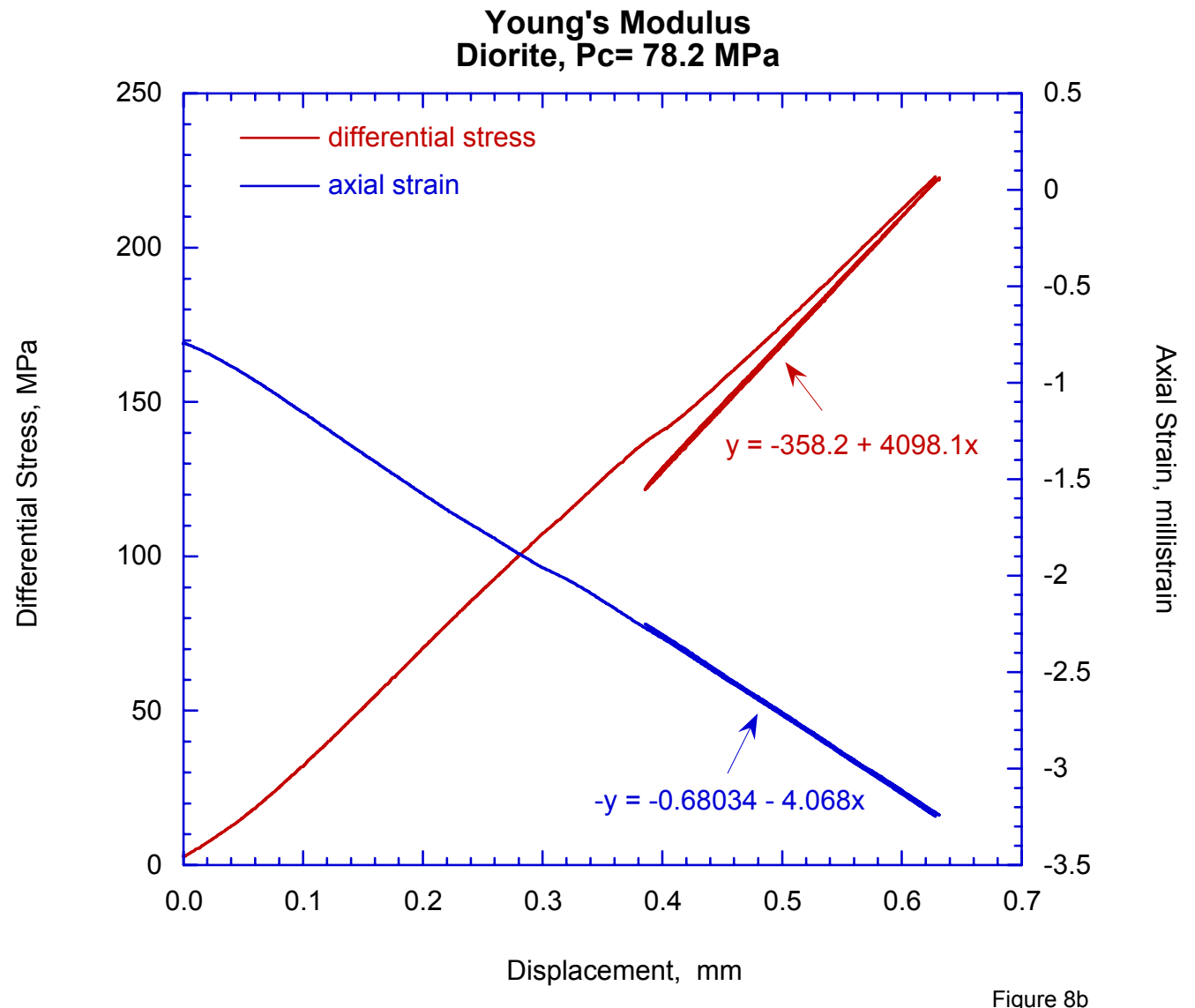




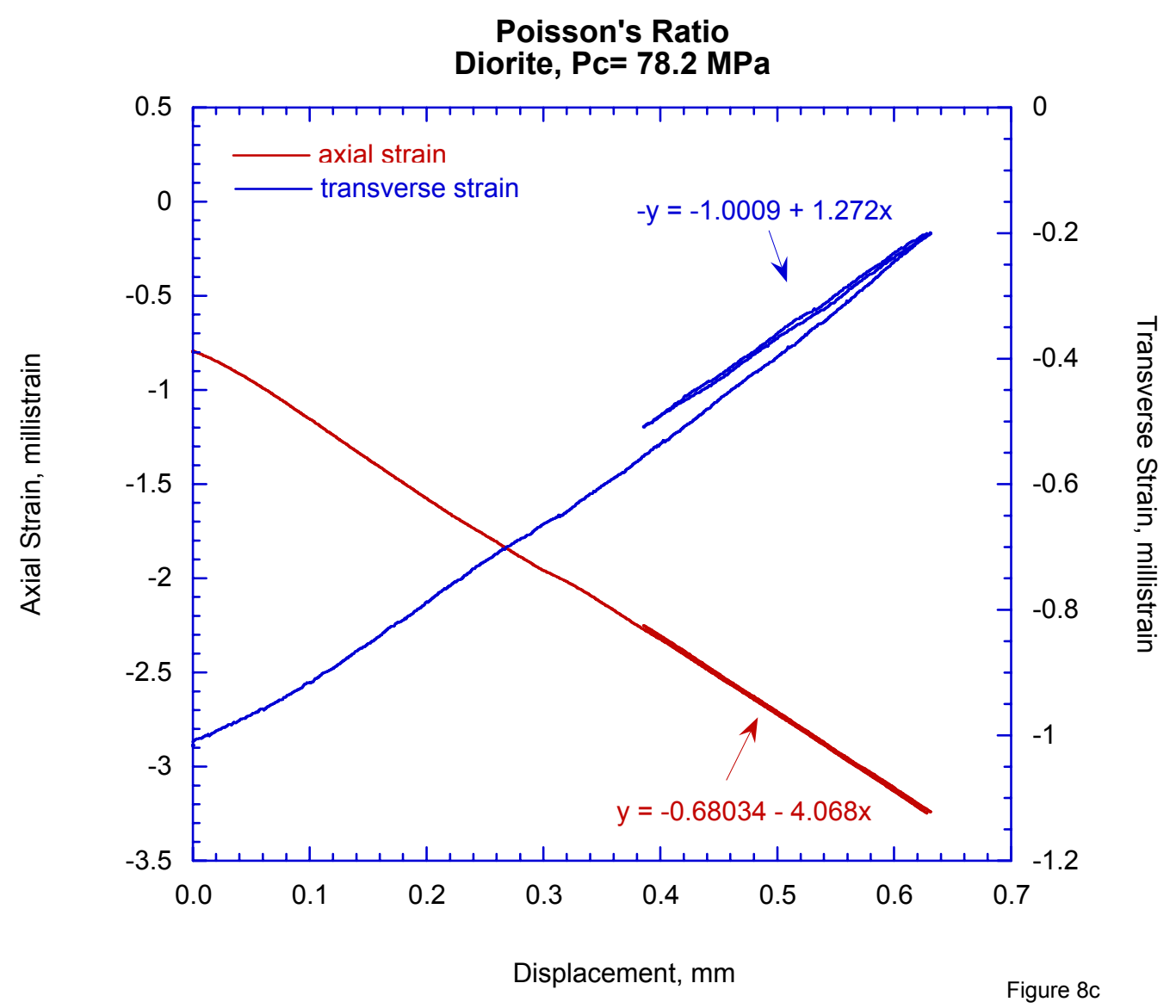




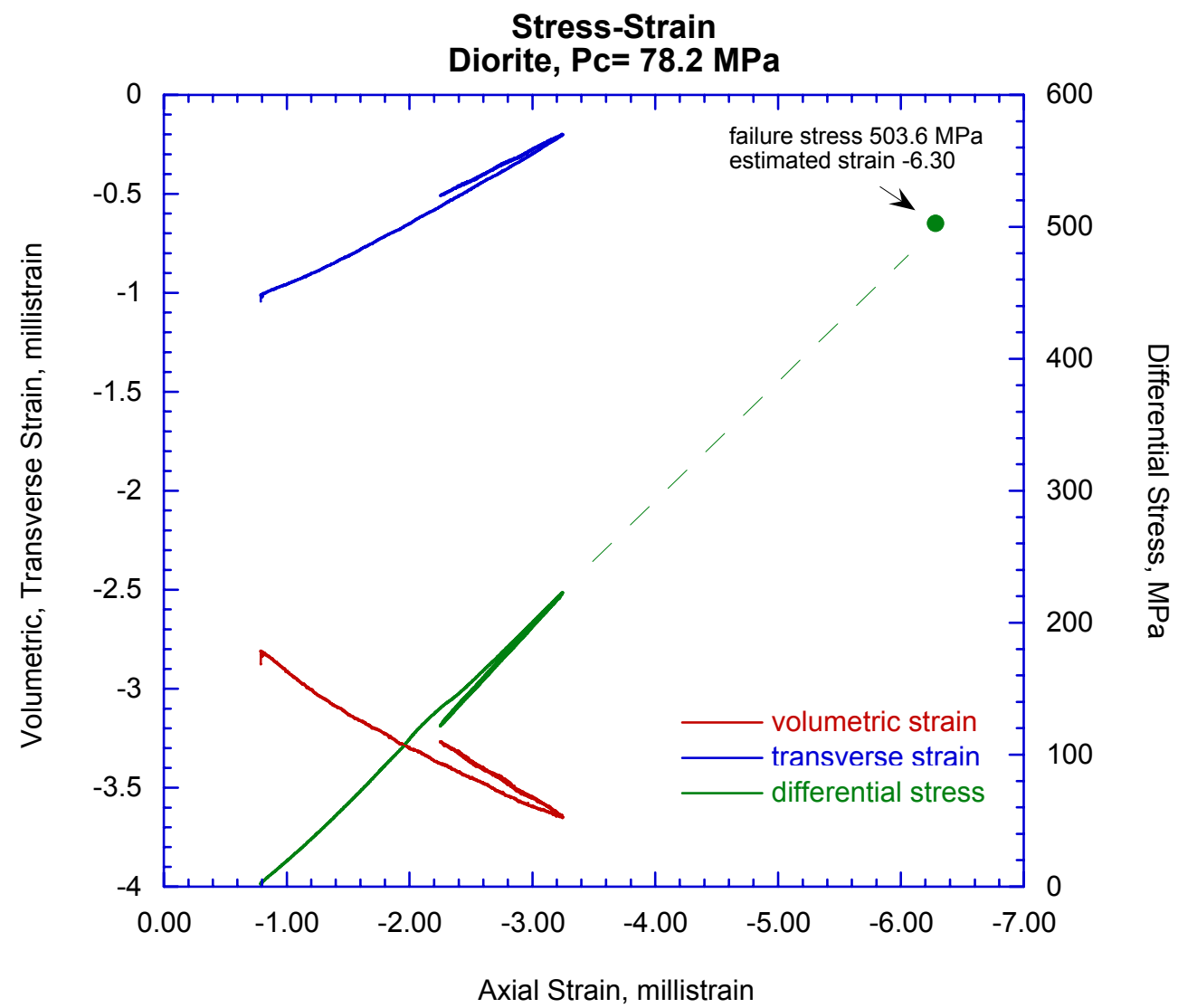

Figure 8d 